Славяноведение 2013-2023

ISSN 2079-8784

URL - $\underline{\text { http: }: / / \text { ras }} . \underline{j e s . s u}$

Все права защищены

Номер 5 Том . 2018

\title{
Э. Дурачинский. Сталин: создатель и диктатор сверхдержавы
}

Борисенок Ю. А.

\section{Аннотация}

Ключевые слова:

Дата публикации: 06.11.2018

Ссылка для цитирования:

Борисенок Ю. А. Э. Дурачинский. Сталин: создатель и диктатор сверхдержавы // Славяноведение - 2018. - Номер 5 С. 120-123 [Электронный ресурс]. URL: https://slav.jes.su/S0869544X0000857-5-1 (дата обращения: 26.04.2023). DOI: 10.31857/S0869544X0000857-5 
Yu. Borisenok

Abstract

Keywords:

Publication date: 06.11 .2018

\section{Citation link:}

Borisenok Y. // Slavianovedenie - 2018. - Issue 5 C. 120-123 [Electronic resource]. URL: https://slav.jes.su/S0869544X0000857-5-1 (circulation date: 26.04.2023). DOI: 10.31857/S0869544X0000857-5

Код пользователя: 0; Дата выгрузки: 26.04.2023; URL - http://ras.jes.su/slav/s207987840000282-9-1-ru Bce права защищены. 